\title{
JNPH
}

Volume 7 No. 1 (April 2019)

(C) The Author(s) 2019

\section{HUBUNGAN PERSEPSI IBU TENTANG KETIDAKCUKUPAN ASI (PKA) \\ TERHADAP PEMBERIAN ASI EKSKLUSIF PADA BAYI DI WILAYAH KELURAHAN KUALA LEMPUING KOTA BENGKULU}

\section{RELATIONSHIP BETWEEN MOTHER'S PERCEPTION OF ASI INCLUSION (PKA) ON EXCLUSIVE ASI ASSUMPTION IN BABIES IN KELURAHAN REGION KUALA LEMPUING BENGKULU CITY}

\author{
DES METASARI ${ }^{1}$, BERLIAN KANDO SIANIPAR ${ }^{2}$ \\ (PRODI KEPERAWATAN (DIII) FIKESUNIVERSITAS DEHASEN BENGKULU \\ Email: desmetasari@unived.ac.id, Hp: 085367324123
}

\begin{abstract}
ABSTRAK
Menurut Riset kesehatan dasar (Riskesdas) tahun 2015, cakupan ASI eksklusif hanya sekitar $38 \%$, sementara pemerintah menargetkan cakupan ASI eksklusif sebesar 80\%.2,3. Cakupan ASI eksklusif di Provinsi Bengkulu mASIh rendah. Sekitar 35\% ibu yang memberikan makanan tambahan kepada bayi sebelum berusia enam bulan ternyata karena mengalami Persepsi Ketidakcukupan ASI (PKA). PKA adalah pendapat ibu yang meyakini bahwa produksi ASI-nya kurang (tidak cukup) untuk memenuhi kebutuhan bayinya dan selanjutnya memberikan makanan pendamping ASI dini. Tujuan penelitian ini adalah untuk mengetahui hubungan antara persepsi ibu tentang ketidakcukupan ASI terhadap pemberian ASI ekslusif pada bayinya. Jenis penelitian ini adalah diskriptif analitik dengan desian crosesectional, sampel dalam penelitian ini adalah seluruh ibu yang mempunyai bayi di kelurahan Kuala Lempuing yang berjumlah 55 orang ibu. HASIl penelitian ini menujukkan sebagian besar (58,2 \%)persepsi ibu baik, sebagian $(63,6 \%)$ ASI Eksklusif dan ada hubungan antara persepsi ibu dengan pemberia ASI eksklusif dimana nilai $p(0,000)<\alpha(0,05)$. Kesimpulan terdapat hubungan antara persepsi ibu dengan pemberia ASI eksklusif, sehingga disarankan untuk menanamkan, mengevaluASI serta menentukan kebijakan program kesehatan, khususnya untuk menurunkan angka kesakitan pada balita.
\end{abstract}

Kata kunci: persepsi ibu, ASI ekslusif, ketidakcukupan ASI

\section{ABSTRACT}

According to the 2015 BASIc Health Research (Riskesdas), exclusive ASI coverage was only around $38 \%$, while the government targeted exclusive breastfeeding coverage of $80 \% .2 .3$. Exclusive breastfeeding coverage in Bengkulu Province is still low. Approximately $35 \%$ of mothers who provide supplementary food to infants before six months of age are found to experience Perception of Inadequate ASI (PKA). PKA is the opinion of mothers who believe that the production of breast milk is insufficient (not enough) to meet the needs of their babies and subsequently provide complementary food for early breastfeeding. The purpose of this study was to determine the relationship between maternal perceptions of the inadequacy of breastfeeding towards exclusive breastfeeding to her baby, The type of this research is 
descriptive analytic with processional design, the sample in this study were all mothers who had babies in the Kuala Lempuing village, amounting to 55 mothers. The results of this study showed that most (58.2\%) mother perceptions were good, partly $(63.6 \%)$ Exclusive breastfeeding and there was a relationship between the perceptions of mothers with exclusive knowledge where the value of $\mathrm{p}(0,000)<\alpha(0.05)$. Conclusions there is a relationship between the perceptions of mothers and exclusive information, so it is advisable to instill, evaluate and determine health program policies, especially to reduce morbidity in infants.

\section{Keywords: mother's perception, exclusive breastfeeding, insufficient breastfeeding}

\section{PENDAHULUAN}

Menyusui secara eksklusif selama enam bulan telah terbukti memiliki banyak manfaat, baik untuk ibu maupun untuk bayinya. Meskipun manfaat-manfaat dari menyusui ini telah dipublikasikan di seluruh dunia, angka cakupan ASI eksklusif masih jauh dari yang diharapkan. Hanya 39\% bayi di bawah enam bulan mendapatkan ASI eksklusif pada tahun 2012. Angka global ini hanya meningkat dengan sangat perlahan selama beberapa dekade terakhir (UNICEF, 2013).

Data menunjukkan bahwa klusif masih rendah. Menurut Riset kesehatan dasar (Riskesdas) tahun 2015, cakupan ASI eksklusif hanya sekitar $38 \%$, sementara pemerintah menargetkan cakupan ASI eksklusif sebesar 80\%.2,3 (Kemenkes RI, 2016). Cakupan ASI eksklusif di Provinsi Bengkulu juga masih rendah bahkan mengalami penurunan dari tahun sebelumnya. Berdasarkan data profil kesehatan Kabupaten / Kota di Provinsi Jawa Tengah tahun 2012, cakupan pemberian ASI eksklusif hanya sekitar $25,6 \%$, menurun dibandingkan tahun 2011 sebesar 45,18\% (Dinkes kota Bengkulu, 2015).

Penyebab utama kegagalan pemberian ASI eksklusif di dunia adalah karena ibu merasa ASI-nya tidak cukup untuk memenuhi kebutuhan bayi. Sekitar 35\% ibu yang memberikan makanan tambahan kepada bayi sebelum berusia enam bulan ternyata karena mengalami persepsi ketidakcukupan ASI (PKA) (Gatti, 2008). PKA adalah pendapat ibu yang meyakini bahwa produksi ASI-nya kurang (tidak cukup) untuk memenuhi kebutuhan bayinya dan selanjutnya memberikan makanan pendamping ASI dini. Beberapa penelitian mengenai PKA di Indonesia menunjukkan bahwa banyak ibu yang merasa ASI-nya tidak cukup untuk memenuhi kebutuhan bayi (Wijayanti, 2012) Banyak faktor yang diduga menjadi penyebab dari PKA. Tiga studi yang dilakukan di Kabupaten Karawang, Kecamatan Tanjung Priok, dan Kecamatan Cilandak menunjukkan bahwa PKA dialami oleh ibu menyusui yang kenaikan berat badan sewaktu hamilnya tidak mencapai kenaikan berat badan yang direkomendasikan sehingga memiliki cadangan lemak kurang dan menyebabkan ibu berhenti memberikan ASI eksklusif sebelum enam bulan. Di Indonesia, sekitar 9 - 21\% wanita usia subur (WUS) di perdesaan memiliki status gizi kurus dan selama kehamilan hanya mengalami kenaikan berat badan sekitar sembilan kilogram (Irawati, 2012).

Berdasarkan uraian dalam latar belakang di atas, didapatkan masalah penelitian banyak ibu yang tidak memberikan ASI ekslusif kepada bayinya karena menganggap ASI saj tidak cukup untuk memenuhi kebutuhan bayinya, sehingga dapat dirumuskan pertanyaan penelitian "Apakah ada hubungan natara persepsi ibu tentang ketidakcukupan ASI terhadap pemberian ASI ekslusif pada bayi di kelurahan Kuala Lempuing?".

$$
\text { Tujuan Umum penelitian ini }
$$
diketahuinya faktor-faktor yang mempengaruhi penurunan nyeri postoperasi sectio caesarea pada ibu postpartum di RS. Raflessia Bengkulu tahun 2017, sedangkan tujuan khusus penelitian ini diketahuinya gambaran intensitas nyeri postoperasi sectiocaesarea pada ibu postpartum sebelum 
dan setelah dilakukan teknik mobilisasi dini, diketahuinya gambaran intensitas nyeri postoperasi pada ibu postpartum sebelum dan setelah dilakukan teknik relaksasi, diketahuinya pengaruh teknik mobilisasi dini terhadap penurunan intensitas nyeri postoperasi SC pada ibu postpartum SC, diketahuinya pengaruh teknik relaksasi terhadap penurunan intensitas nyeri pada ibu postpartum SC di Rumah sakit Raflessia Bengkulu tahun 2017.

Manfaat praktis penelitian ini diharapkan dapat memberi masukan kepada pihak rumah sakit dalam memberikan pelayanan kesehatan terutama mengajarkan teknik mobilisasi dini dan teknik relaksasi pada ibu postpartum dengan SC sehingga dapat mengurangi rasa nyeri yang ibu alami dan akan memaksimalkan kegiatan ibu dalam merawat bayinya dan laktasi.

\section{METODE}

Penelitian ini menggunakan jenis penelitian diskriptif analitik dengan rancangan penelitian crossectional dengan kerangka hubungan antara konsep-konsep yang ingin diamati atau diukur melalui penelitian-penelitian yang akan dilakukan, dimana variabel-variable penelitian diukur dalam satu waktu atau waktu yang bersamaan.

\section{HASIL}

Data yang diperoleh kemudian diolah menggunakan program komputer dengan SPSS 17, dari hASIl pengolahan data maka dilakukan analisis Univariat untuk mengetahui gambaran distribusi frekuensi masing - masing variabel penelitian dan analisis Bivariat untuk mengetahui hubungan antar variabel yaitu (persepsi ibu tentang kecukupan ASI dengan pemberian ASI ekslusif) Adapun hasil analisisnya sebagai berikut.
Tabel 1.Distribusi Frekuensi Responden Berdasarkan Persepsi ibu terhadap ketidakcukupan ASI eksklusif di Kelurahan Kuala Lempuing Kota Bengkulu Tahun 2019

\begin{tabular}{cccc}
\hline No & $\begin{array}{c}\text { Persepsi Frekuensi } \\
\text { Ibu }\end{array}$ & Persentase (\%) \\
\hline 1 & $\begin{array}{c}\text { Kurang } \\
\text { Baik }\end{array}$ & 23 & 41.8 \\
\hline 2 & Baik & 32 & 58.2 \\
\hline & Total & 55 & 100 \\
\hline
\end{tabular}

Sumber : Data penelitian 2019

Berdasarkan Tabel 1, menunjukkan bahwa dari 55 responden sebagian besar $(58,2$ \%) persepsi ibu baik.

Tabel 2. Distribusi Frekuensi Responden Berdasarkan Pemberian ASI eksklusif di Kelurahan Kuala Lempuing Kota Bengkulu Tahun 2019

\begin{tabular}{cccc}
\hline No & $\begin{array}{c}\text { Pemberian } \\
\text { ASI ekslusif }\end{array}$ & Frekuensi & $\begin{array}{c}\text { Persentase } \\
(\mathbf{\%})\end{array}$ \\
\hline 1 & $\begin{array}{c}\text { Tidak ASI } \\
\text { Eksklusif }\end{array}$ & 20 & 36.4 \\
\hline 2 & ASI Eksklusif & 35 & 63.6 \\
\hline & Total & 55 & 100 \\
\hline
\end{tabular}

Sumber : Data penelitian 2019

Berdasarkan Tabel 2, Tabel diatas menunjukkan bahwa dari 55 responden sebagian (63,6 \%) ASI Eksklusif.

Tabel 3 Hubungan persepsi ibu tentang ketidakcukupan ASI dengan pemberian ASI ekslusif di kelurahan Kuala Lempuing Kota Bengkulu 


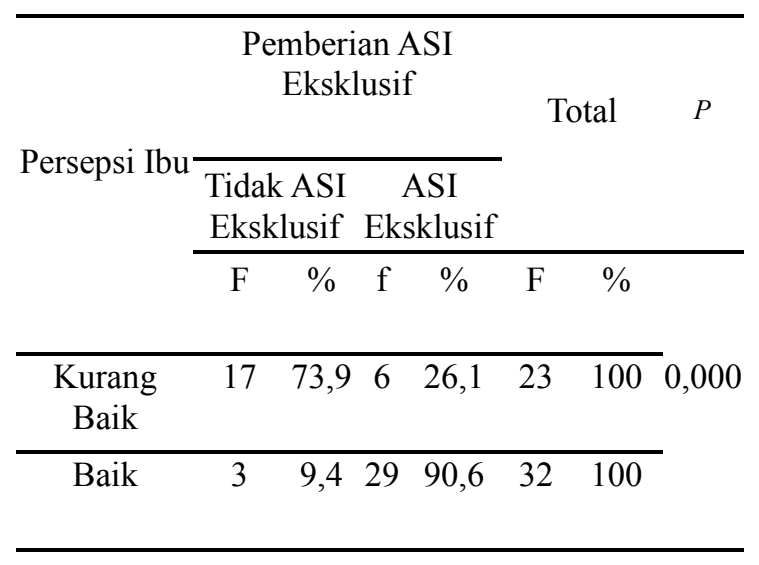

Sumber : Data penelitian 2019

Berdasarkan tabel 3 terhadap hubungan antara persepsi ibu tentang ketidakcukupan ASI dengan pemberian ASI ekslusif pada bayi di kelurahan Kuala Lempuing kota Bengkulu dengan nilai $p \leq 0,05$ dan nilai $p(0,000)$.

\section{PEMBAHASAN}

Persepsi sangat ditentukan oleh banyak hal, yaitu melalui faktor personal dan faktor situasional. Faktor personal adalah faktorfaktor internal yang ada didalam diri orang tersebut seperti kesukaan, kondisi fisik dan lain sebagainya. Sedangkan faktor situasional adalah faktor diluar diri orang tersebut yang mempengaruhinya antara lain pendapat maupun pengaruh orang lain ketika orang tersebut berada pada satu proses untuk mempersepsi.

Air Susu Ibu (ASI) merupakan suatu emulsi lemak dalam larutan protein, laktosa, dan garam-garam organik yang dikelurkan oleh kelenjar mamari manusia. Sebagai satusatunya makanan alami yang berasal dari ibu, ASI menjadi makanan terbaik dan sempurna untuk bayi karena mengandung zat gizi sesuai kebutuhan untuk pertumbuhan dan perkembangan bayi.

Persepsi adalah proses internal yang memungkinkan kita memilih, mengorganisasikan, dan menafsirkan rangsangan dari lingkungan kita (Mulyana,2005, p.167). Sedangkan menurut Rahmat, persepsi adalah memberikan makna pada stimuli indrawi ( Rakhmat, 2009, p.51). Menurut Wood (1997, p.40) menjelaskan bahwa persepsi adalah proses aktif dari seleksi, organisasi dan interpretasi terhadap manusia, objek, peristiwa dan aktivitas. Persepsi merupakan proses aktif. Manusia fokus lalu mengorganisasikan dan menginterpretasi apa yang telah diperhatikannya secara selektif tersebut.

Persepsi sangat ditentukan oleh banyak hal, yaitu melalui faktor personal dan faktor situasional. Faktor personal adalah faktorfaktor internal yang ada didalam diri orang tersebut seperti kesukaan, kondisi fisik dan lain sebagainya. Sedangkan faktor situasional adalah faktor diluar diri orang tersebut yang mempengaruhinya antara lain pendapat maupun pengaruh orang lain ketika orang tersebut berada pada satu proses untuk mempersepsi (Maritalia,12.00.00).

ASI eksklusif adalah pemberian ASI (air susu ibu) sedini mungkin setelah persalinan, diberikan tanpa jadwal dan tidak diberikan makanan lain, walaupun hanya air putih sampai bayi berumur 6 bulan. Setelah itu diberi makanan padat pendamping yang cukup dan sesuai. sedangkanASI tetap diberikan sampai usia 2 tahun atau lebih (Purwanti, 2014).

Memberikan ASI secara eksklusif berarti keuntungan untuk semua, bayi akan lebih sehat, cerdas, dan berkepribadian baik, ibu akan lebih sehat dan menarik. Perusahaan, lingkungan dan masyarakat pun lebih mudah mendapatkan keuntungan (Utami Roesli, 2012).

\section{KESIMPULAN}

Berdasarkan hasil penelitian tentang hubungan persepsi ibu tentang ketidakcukupan ASI dengan pemberian ASI eksklusif di kelurahan kuala lempuing kota Bengkulu Tahun 2019, maka Peneliti dapat menyimpulkan sebagai berikut : Sebagian besar responden persepsi ibu baik, Sebagian besar responden pemberian ASI eksklusif, Terdapat hubungan antara persepsi ibu tentang ketidakcukupan ASI dengan 
pemberian ASI eksklusif

\section{SARAN}

Hasil penelitian ini kiranya dapat dijadikan masukan dan berguna dalam menanamkan, mengevaluasi serta menentukan kebijakan program kesehatan, khususnya untuk menurunkan angka kesakitan pada balita.

\section{DAFTAR PUSTAKA}

Arikunto, S. (2010). Prosedur penelitian : suatu pendekatan praktik. Jakarta: Rineka Cipta.

Astutik, R.Y. (2014). Payudara dan LaktASI. Jakarta: Salemba Medika.

Hidayat, A.A. (2009). Metode Penelitian Keperawatan dan Teknik Analisis Data. Jakarta Salemba Medik

Maritalia, D. (2012). Asuhan Kebidanan Nifas dan Menyusui. Yogyakarta: Pustaka Pelajar.

Nugroho, T. (2011). ASI dan Tumor Payudara. Yogyakarta: Nuha Medika.

Nursalam. (2008). Konsep dan Penerapan Metodologi Penelitian Ilmu Keperawatan. Jakarta : Salemba Medika.

Dinas Kesehatan Kota Bnegkulu. (2017). Profil kota Bengkulu.

Pudjiadi,S. (2005). Ilmu Gizi Klinis Pada Anak. Edisi keempat FKUI. Jakarta: Balai Penerbit FKUI.

Purwanti, H.S. (2004). Konsep Penerapan ASI Eksklusif Buku Saku Bidan. Jakarta: EGC.

Surakhmad. 2001. Penelitian Ilmiah: Dasar, Metode dan Teknik. Bandung:

Tarsito. Suryabrata, Sumadi. 2002. Psikologi pendidikan. Jakarta: PT. Raja Grafindo

Persada.

Jeffry S, Nevid, Spencer, Beyerly. (2005) Psikologi Abnormal jilid II. Jakarta :Erlangga. 